Original Research Paper

\title{
MYSIMBA: Koswer Pembelajaran Multimedia Interaktif Bagi Pembelajaran Simpulan Bahasa Pelajar Darjah 6
}

\author{
Muhammad Shukri Khalid ${ }^{1}$, Roznim Mohamad Rasli ${ }^{2}$
}

${ }^{1}$ Program of ISMP (Information Technology), Department of Computing. Faculty of Art, Computing \& Creative Industry. Universiti Pendidikan Sultan Idris. Tanjong Malim, Malaysia.

${ }^{2}$ Department of Computing. Faculty of Art, Computing \& Creative Industry. Universiti Pendidikan Sultan Idris. Tanjong Malim, Malaysia.

Article History
Received:
14.11 .2021
Revised:
17.12.2021
Accepted:
23.12.2021
*Corresponding Author:
Roznim Mohamad Rasli
Email:
roznim@fskik.upsi.edu.my

This is an open access article, licensed under: $\mathrm{CC}-\mathrm{BY}$-SA
Abstrak: Penyelidikan ini yang lebih tertumpu kepada asas salah satu bentuk peribahasa yang terdapat dalam silibus mata pelajaran bahasa Melayu iaitu simpulan bahasa. Metadologi Kajian dalam pembangunan koswer ini adalah menggunakan model ADDIE. Terdapat lima fasa terlibat dalam pembangunan koswer ini. Kaedah analisis yang digunakan fasa ini melibatkan analisis kandungan perlu difokuskan dari segi kesesuaian kandungan dan sasaran pengguna. Hal ini adalah kerana supaya koswer yang ingin dibangunkan mencukupi dan selaras dengan keperluan pengguna dari segi perisian dan perkakasan. Perisian yang digunakan adalah seperti Microsoft Words dan Microsoft Powerpoint dan perisian lain yang berkaitan seperti server dan sebagainya. Keberhasilan produk akan diuji melalui Technology Acceptance Model (TAM) yang digunakan dalam fasa penilaian yang akan menilai dari segi kebolehgunaan. Tegasnya, koswer ini juga dibangunkan untuk memudahkan pengajaran bagi pengajar atau guru-guru yang mengajar murid sekolah dan mengimplementasikan penggunaan multimedia dalam proses PdP. Ini bertujuan untuk menarik minat murid sekolah dalam proses mengenali simpulan bahasa dan seterusnya memudahkan proses PdP di dalam kelas. Impaknya, diharapkan koswer ini dapat memahirkan murid-murid sekolah terhadap penggunaan simpulan bahasa dalam sesi PdP dan kehidupan seharian.

Kata Kunci: ADDIE, Koswer, Teknologi Pembelajaran.

MYSIMBA: Interactive Multimedia Learning Courseware for Grade 6 Students' Idioms Learning

Abstract: This research is more focused on basic one form of proverbs found in the Malay language syllabus of idioms. Research Methodology in the development of this courseware is using the ADDIE model. There are several phases involved in the development of this course. The method of analysis used in this phase involves content analysis should be focused in terms of content suitability and target users. This is because so that the courseware to be developed is adequate and in line with the needs of users in terms of software and hardware. The software used is like Microsoft Words and Microsoft Powerpoint and other related software such as servers and so on. Product success will be tested through the Technology Acceptance Model (TAM) used in the evaluation phase which will evaluate in terms of usability. Strictly speaking, this courseware was also developed to facilitate teaching for teachers or teachers who teach school children and implement the use of multimedia in the PdP process. This aims to attract school students in the process of recognizing idioms and further facilitate the PdP process in the classroom. As a result, it is hoped that this course will be able to educate school children on the use of idioms in PdP sessions and daily life.

Keywords: ADDIE, Courseware, Instructional Technology. 


\section{Pendahuluan}

Sistem pendidikan pada masa kini sedang mengalami proses perubahan yang pesat selaras dengan peredaran masa. Terdapat pelbagai kaedah baharu telah diperkenal dan diaplikasikan supaya pengajaran dan pembelajaran (PdP) guru di dalam kelas menjadi lebih interaktif dan dapat menarik minat pelajar untuk belajar dan seterusnya sesuatu pembelajaran itu menjadi lebih bermakna. Justeru itu, teknologi maklumat dan komunikasi (ICT) telah diperkenalkan khususnya di dalam bidang pendidikan. ICT adalah program yang memberi tumpuan kepada teori umum dan amalan PdP yang melibatkan pengaplikasian teknologi yang didasari oleh prinsip dasar psikologi pendidikan. Prinsip dasar psikologi pendidikan adalah termasuk seni mengajar, perancangan dan pentadbiran berkaitan pendidikan, isu keselamatan dan kesihatan sekolah serta asas pendidikan sosial. Di dalam bidang pendidikan, kebanyakan ahli akademik seharusnya mempunyai beberapa perancangan untuk mengajar para pelajar menggunakan teknologi. Pendidikan juga boleh disampaikan kepada pelajar melalui penggunaan komputer untuk membolehkan pelajar selesa menggunakan pendekatan berasaskan teknologi berbanding buku.

Menurut UNESCO [1], pendidikan ICT juga menjadi tunjang kepada interaksi dua hala di dalam proses PdP. Melalui penggunaan teknologi, ahli akademik dapat menggantikan papan tulis dengan papan digital interaktif. Secara tidak langsung para pelajar akan didedahkan dengan penggunaan komputer riba (laptop) atau peranti lain untuk belajar di dalam kelas. Selain itu, pendidikan ICT juga menggalakkan pembelajaran kendiri di mana-mana dan digunakan pada bila- bila masa sahaja. Justeru, pengaplikasian teknologi dan strategi pembelajaran kendiri menjurus kepada kemahiran berfikir aras tinggi serta menjana pemikiran yang kritis, kreatif dan inovatif. Seterusnya, ini akan melahirkan modal insan yang lebih bersedia untuk menghadapi perubahan drastik teknologi khususnya persekitaran pendidikan 4.0 dan revolusi industri 4.0.

Kini, penggunaan ICT dalam dunia pendidikan telah diperkenalkan di banyak sekolah melalui PdP subjek ICT. Pendidikan ICT memainkan peranan yang penting dalam menjadikan Malaysia sebuah negara yang maju pada masa ini.

Terdapat pelbagai projek berasaskan ICT telah dirancang dan dilaksanakan bertujuan untuk meningkatkan taraf ekonomi negara, peningkatan perdagangan, pentadbiran sistematik dan semestinya taraf pendidikan rakyat. Justeru, kerajaan telah mengenalpasti pelbagai alternatif untuk memastikan pendidikan rakyat dapat ditingkatkan. Salah satu pendekatan yang sering digunakan ialah perisian instruksional atau lebih dikenali sebagai koswer multimedia interaktif. Secara kesimpulannya, koswer ini merupakan satu alat bahan bantu mengajar (ABM) yang sedang giat digunakan dan lebih menarik kerana mempunyai kombinasi teks, audio dan video yang bersifat interaktif dan seterusnya dapat menarik minat pelajar semasa proses PdP di dalam bilik darjah.

Menurut Stephen [2], di zaman teknologi yang serba canggih kini, pelajar universiti turut didedahkan dengan pelbagai kaedah dan strategi pembelajaran bagi melahirkan modal insan kelas pertama. Sebelum ini, terdapat dua (2) jenis persekitaran pembelajaran pendidikan tradisional. Pertama, persekitaran pengajaran tradisional yang masih banyak digunakan di sekolah yang secara lazimnya melibatkan gaya mengajar orang zaman dahulu melalui pembacaan. Sebagai contohnya, para pelajar akan duduk secara diam, dan bergilir-gilir untuk membaca topik pembelajaran itu, sehingga setiap orang dipanggil. Guru membaca topik pembelajaran itu, sehingga setiap orang dipanggil. Guru akan mendengar pembacaan setiap peringkat, dan mereka hanya perlu untuk belajar dan menghafal tugasan tersebut. Pada akhir modul, ujian bertulis atau peperiksaan lisan akan dijalankan di mana proses ini dikenali sebagai kajian tugasan bacaan. Selain itu, persekitaran pengajaran berasaskan ganjaran di mana kaedah pengajaran tradisional diajar dengan memastikan pelajar diberi ganjaran untuk usaha mereka, menggunakan waktu kelas dengan cekap dan melaksanakan peraturan yang jelas untuk menguruskan tingkah laku pelajar. Para guru memberikan pengetahuan tentang tingkah laku yang harus dipraktikkan dalam pembelajaran. Namun begitu, proses PdP tetap berlangsung di dalam kelas yang bersifat statik dan sehala sedangkan setiap pelajar itu mempunyai tahap intelektual dan tingkah laku yang berbeza-beza. Bagi mengatasi permasalahan ini, pendidikan progresif telah dicadangkan dan diperkenalkan. Di dalam pendidikan progresif ini, ia dapat memberikan perhatian yang lebih kepada keperluan setiap pelajar kerana tidak semua pelajar berada di tahap pemahaman yang sama. Justeru itu, pembaharuan pendidikan dapat dipelajari dari sudut yang berbeza melalui aplikasi yang tidak bersesuaian.

Antara kaedah pengajaran moden seperti penggunaan koswer di dalam proses PdP adalah lebih efektif melalui teknik menyoal, menjelaskan, demonstrasi dan kolaborasi berbanding pendekatan tradisional yang statik dan bersifat sehala. Di antara kelebihan yang terdapat di dalam koswer adalah penyediaan navigasi mudah alih untuk pelajar berinteraksi bersama dan menyediakan pembelajaran 
yang lebih efisien dan menarik untuk setiap pelajar. Pelajar tidak perlu menggunakan buku tebal atau buku rujukan lain untuk memahami PdP kerana isi kandungan, latihan pengukuhan, permainan dan koleksi video telah tersedia dirangkum di dalamnya.

Kesepaduan di dalam koswer multimedia interaktif ini juga amat bersesuaian untuk diterapkan di dalam PdP berkaitan komputer. Ini adalah kerana, proses PdP menggunakan pelbagai platform yang perlu dicapai satu per satu dan akan mengambil masa yang agak lama untuk menyelesaikannya. Selain itu, kandungan berkaitan komputer yang agak kabur dan kompleks menyukarkan pelajar untuk menggunakan koswer yang bakal dibina di dalam topik Simpulan Bahasa. Justeru, kajian ini bertujuan membangunkan koswer multimedia interaktif untuk topik Simpulan Bahasa yang memfokuskan kepada strategi pembelajaran kendiri dengan menggunakan koswer sebagai bahan teknologi pengajaran.

\section{Kajian Literatur}

Dalam kajian literatur terkandung maklumat mengenai tinjauan literatur yang bersesuaian, kajian ke atas produk lampau, kelebihan dan kekuatan produk yang digunakan berbanding produk semasa.

\subsection{Teknologi Maklumat}

Menurut Akmal [3] Teknologi Maklumat (IT) didefinisikan sebagai sesuatu yang dapat memudahkan kehidupan seharian manusia serta dapat meningkatkan produktiviti dan keselamatan manusia. Ini juga turut disokong oleh Brendon et al [4] yang bersetuju IT dapat meningkatkan motivasi dalam kalangan pelajar. Melalui implimentasi teknologi multimedia yang terdiri multimedia yg terdiri daripada elemenelemen teks, imej, video, audio, animasi, dan interaktiviti. Teknologi multimedia ini telah memudahkan pemahaman khususnya bagi pembelajaran yang bersifat abstrak [5] [6] [7] [8] [9] [10].

Menurut Hisham et al. [11] menyatakan bahawa IT dapat menjadikan setiap urusan menjadi lebih cepat dan mudah serta amat berkesan dalam kalangan rakyat kini. Ini juga turut disokong oleh Rahman et al. [12] yang turut bersetuju IT juga dapat menanamkan adab dalam kalangan pelajar terhadap pengendalian teknologi maklumat dan teknologi komputer mengikut syariat Islam yang sebenar serta menelusuri perkembangan IT dalam kehidupan insan yang telah banyak menyumbang kepada kejayaan pembangunan ekonomi, pendidikan dan pembentukan sahsiah ummah. Ini adalah kerana IT khasnya melalui integrasi teknologi multimedia yang melibatkan elemen-elemen multimedia seperti teks, gambar, suara, dan animasi yang dapat dijalankan di media elektronik iaitu PC (Personal Computer).

Namun, terdapat juga penulis yang tidak bersetuju dan menyatakan IT terlalu memberitumpuan terhadap teknologi berbanding teori, penyelidikan dan pedagogi [13]. Secara kesimpulannya, di antara bidang yang terkesan dalam penggunaan IT adalah bidang pendidikan sama ada di peringkat sekolah rendah, menengah dan peringkat tinggi.

\subsection{IT Dalam Pendidikan}

Penggunaan IT dalam kalangan pendidik dan pelajar dalam PdP amat penting untuk keperluan pendidikan semasa. Anjakan paradigma ini dilihat memberi impak besar kepada pendidikan khususnya di Institusi Pengajian Tinggi AWam (IPTA) yang menjadikan media teknologi ini sebagai keperluan utama bagi pendidik dan pelajar itu sendiri [14]. Terdapat pelbagai metod atau kaedah yang digunakan di antaranya perisian multimedia interaktif (koswer), web, realiti maya, augmented reality, gamifikasi, aplikasi mobil dan koswer. Menurut Salsidu et al [15] menyatakan penggunaan multimedia dalam pendidikan, mampu memberi kesan positif terhadap pencapaian dan penguasaan pelajar dalam sesuatu mata pelajaran, mewujudkan pembelajaran berbentuk interaktif antara pelajar dan perisian serta mencipta suasana pembelajaran yang lebih menarik.

\subsection{Koswer Dalam PdP}

Istilah "Koswer" digunakan untuk mewakili pakej atau modul kuliah dalam bentuk digital atau elektronik, yang disampaikan melalui pembelajaran dalam talian sebagai bahan pengajaran. Komponen kursus dalam talian ini boleh menjadi asas yang diterjemahkan kepada empat (4) model berbeza iaitu Model Domain, Konteks Pembelajaran, Model Pedagogi, Model Sumber Pembelajaran dan Model Kursus [16]. Menurut Norhasyimah Hamzah [17], menyatakan bahawa Pengajaran dan PdP koswer yang berbantukan komputer ini juga merupakan suatu alternatif pilihan kepada pelajar untuk belajar mengikut keupayaan diri sendiri. Koswer pembelajaran berbantukan komputer yang dihasilkan adalah berpusatkan kepada pelajar di mana pelajar diberi peluang untuk memilih subtopik yang ingin dipelajari dan merancang pembelajaran mengikut kemampuan sendiri. 


\subsection{Koswer Dalam PdP Simpulan Bahasa}

\subsubsection{Kelebihan}

Menurut Noor \& Salih [18] menyatakan bahawa koswer dapat mengatasi miskonsepsi dan meningkatkan kefahaman murid bagi topik fasa-fasa bulan. Refleksi awal menunjukkan murid mempunyai miskonsepsi terhadap sesuatu istilah. Oleh itu, melalui koswer ini dapat menggunakan pendekatan yang sama dalam membantu murid untuk memahami topik simpulan bahasa dengan lebih baik. Koswer pembelajaran ini adalah untuk memudahkan proses PdP seterusnya dapat mencapai tahap kemahiran kognitif pembelajaran berasaskan Taksonomi Bloom iaitu asas kemahiran pengetahuan, pemahaman dan aplikasi. Melalui koswer pembelajaran ini murid dapat menguasai pengetahuan asas berasaskan dalam topik simpulan bahasa.

\subsubsection{Kelemahan}

Menurut Hafizul Fahri Hanafi et al. [19] menyatakan suatu peralatan seperti teknologi komputer atau koswer yang merupakan alat perisian kursus multimedia interaktif adalah tidak sesuai digunakan oleh pelajar sekiranya ia tidak menggalakkan pelajar berfikir secara mendalam apa yang hendak dipelajari dan sekiranya alat ini tidak dapat membantu proses pembelajaran. Oleh itu, murid tidak boleh bergantungnya sepenuhnya kepada koswer pembelajaran semata-mata untuk memahami topik simpulan bahasa. Menurut beliau juga model pembelajaran dan reka bentuk instruksi mengikut teori pembelajaran yang sesuai akan diguna pakai di dalam pembangunan perisian multimedia ini. Aspek yang perlu diambil kira adalah kualiti dari segi reka bentuk antara muka, reka bentuk intruksi, dan penilaian ke atas perisian tersebut. Tegasnya, koswer pembelajaran tersebut dapat berfungsi dengan baik untuk murid mempelajari topik simpulan

\subsection{Perbandingan Koswer Semasa}

\subsubsection{Penggunaan Koswer Multimedia Animasi Visual Terhadap Pencapaian Pelajar dalam} Mata Pelajaran Matematik

Ramai pelajar yang bermasalah dalam topik Pelan dan Dongakan. Ini kerana pelajar sukar untuk membayangkan objek yang tersembunyi melalui proses pengajaran dan pembelajaran (PdP) secara konvensional. Penyelidik telah membangunkan satu koswer multimedia animasi visual dalam topik Pelan dan Dongakan dengan menerapkan kesemua elemen-elemen yang dapat membantu meningkatkan kemahiran visual iaitu elemen animasi, video, audio, grafik dan teks. Tujuan koswer ini dibangunkan adalah bertujuan untuk mengetahui penggunaan koswer multimedia animasi visual terhadap pencapaian pelajar bagi mata pelajaran Matematik di sekolah menengah. Tegasnya, koswer ini dibangunkan adalah untuk menggambarkan penggunaan koswer multimedia animasi visual supaya dapat membantu meningkatkan pencapaian Matematik di dalam bilik darjah terutama yang tidak melibatkan pengiraan [20].

\subsubsection{Pembangunan Koswer Pembelajaran Berbantukan Komputer bagi Topik Proses Penerbitan Animasi}

Teknologi Animasi merupakan salah satu kursus penting kepada pelajar daripada Fakulti Pendidikan Teknikal dan Vokasional, UTHM. Koswer ini dibangunkan bertujuan untuk merekabentuk, membangunkan dan menilai koswer pembelajaran berbantukan komputer bagi topik prosespenerbitan animasi. Selain itu, koswer ini menguji kebolehgunaan koswer pembelajaran yang dibangunkan terhadap tiga orang pakar. Metodologi pembangunan adalah berdasarkan model ASSURE yang mempunyai enam asas fasa iaitu fasa analisis pelajar, fasa nyatakan objektif, fasa pilih kaedah, media dan bahan, fasa guna media dan bahan, fasa libatkan pelajar dan fasa terakhir fasa nilai dan kaji semula. Tegasnya, pembangunan koswer pembelajaran berbantukan komputer bagi topik proses penerbitananimasi ini diharapkan dapat membantu pelajar untuk lebih memahami topik tersebut [21].

\subsubsection{Koswer Multimedia Pemujukan Kesedaran Obesiti Ke Atas Pengetahuan, Kesedaran dan Motivasi Murid Yang Berbeza Jenis Motivasi}

Projek ini dijalankan bertujuan untuk merekabentuk, membangun dan mengkaji kesan koswer multimedia pemujukan ke atas pengetahuan dan persepsi kesedaran terhadap obesiti dan juga persepsi motivasi terhadap bahan pengajaran dalam kalangan murid Tahun Lima. Terdapat dua mod persembahan koswer iaitu Koswer Multimedia Pemujukan Kesedaran Obesiti (Maklum Balas Penjelasan) (PerMOss 1) dan Koswer Multimedia Pemujukan Kesedaran Obesiti (Maklum Balas Pembetulan) (PerMOss 2). Perbezaan mod persembahan koswer ini adalah untuk membezakan 
perbezaan fungsi kedua-dua koswer tersebut dalam sesuatu situasi. Hasilnya, dapatan menunjukkan bahawa adaptasi prinsip maklum balas penjelasan dalam persekitaran pembelajaran multimedia memberi impak yang positif dalam meningkatkan pengetahuan, persepsi kesedaran dan persepsi motivasi terhadap obesiti dalam kalangan murid. Penggunaan prinsip multimedia ini dapat mengurangkan beban kognitif murid untuk belajar seterusnya memudahkan murid untuk memahami kandungan pembelajaran dan menjadikan pembelajaran lebih efektif. Tegasnya, pembangunan koswer multimedia dalam projek ini telah menyumbang kepada menambahkan bilangan koswer berasaskann komputer untuk mendedahkan murid kepada topik bahaya obesiti dan gaya hidup sihat yang masih kurang dibangunkan terutamanya bagi konteks kanak-kanak di negara ini [22].

Secara kesimpulannya, melalui tiga (3) contoh pembangunan koswer yang telah dijalankan, terdapat kelebihan dan kelemahan yang boleh kita pelajari melalui situasi tersebut. Melalui pemerhatian ini kita dapat mengambil inisiatif untuk membangunkan koswer yang lebih baik dari sebelumnya.

Jadual 1. Perbandingan Koswer Semasa

\begin{tabular}{|c|c|c|c|}
\hline Input & $\begin{array}{l}\text { Koswer dalam } \\
\text { Pembelajaran } \\
\text { Matematik }\end{array}$ & $\begin{array}{c}\text { Koswer } \\
\text { Pembelajaran } \\
\text { Penerbitan Animasi }\end{array}$ & $\begin{array}{l}\text { Koswer } \\
\text { Kesedaran } \\
\text { Obesiti }\end{array}$ \\
\hline 离 & $\begin{array}{l}\text { Koswer ini mudah } \\
\text { digunakan dandifahami } \\
\text { denganmudah serta } \\
\text { dapatmenarik minat } \\
\text { orang ramai untuk } \\
\text { menggunakannya. }\end{array}$ & $\begin{array}{l}\text { Koswer ini mempunyai } \\
\text { komunikasi dua hala } \\
\text { antara koswer dan } \\
\text { pengguna. } \\
\text { Pembelajaran lebih } \\
\text { menarik dan interaktif. }\end{array}$ & $\begin{array}{l}\text { Koswer ini akan } \\
\text { membimbing dan } \\
\text { mengingatkan } \\
\text { pengguna } \\
\text { mengenai } \\
\text { kandungan } \\
\text { pembelajaran yang } \\
\text { perlu dilakukan. }\end{array}$ \\
\hline 节 & $\begin{array}{l}\text { Pembangunan koswer } \\
\text { yang memerlukan } \\
\text { perbelanjaan yang } \\
\text { tinggi. }\end{array}$ & $\begin{array}{l}\text { Pembangunan sesuatu } \\
\text { koswer pendidikan adalah } \\
\text { lebih bersesuaian dan } \\
\text { efektif jika menggunakan } \\
\text { model ADDIE. }\end{array}$ & $\begin{array}{l}\text { Input koswer yang } \\
\text { terlalu kompleks } \\
\text { dengan pengisian } \\
\text { dan }\end{array}$ \\
\hline
\end{tabular}

Pembangunan koswer MySimba Apps terlebih dahulu akan melihat kepada

aspek input bahan pengajaran yang bersesuaian, berfokus kepada
interaktiviti dan reka bentuk dari koswer sedia ada di pasaran. Selain itu,
paparan muka koswer adalah lebih ringkas dan menarik dari sebelumnya,
kos pengeluaran yang berbaloi dengan koswer yang akan dibangunkan dan
seterusnya metodologi pembangunan bersesuian dengan pembangunan
sesuatu koswer.

\section{Metodologi Pembangunan}

\subsection{Perbandingan Metodologi}

Beberapa model yang digunapakai dalam membangunkan sebuah aplikasi, iaitu ADDIE, ASSURE dan Spire / Waterfall. Perbandingan ketiga-tiga metodologi boleh dilihat pada Jadual 2.

\subsection{Model ADDIE}

Model ADDIE adalah salah satu model yang paling biasa digunakan dalam bidang reka bentuk pengajaran yang bertindak sebagai panduan untuk menghasilkan reka bentuk yang berkesan. Model ini adalah pendekatan yang membantu pereka pengajar, pemaju, atau bahkan guru untuk mewujudkan reka bentuk pengajaran yang berkesan dengan menggunakan model ADDIE pada sebarang produk pengajaran. Malah unsur-unsur yang dibuat dengan mengikuti model ADDIE boleh digunakan dalam mana-mana persekitaran secara dalam talian atau bersemuka. Proses sistematik ini diwakili dalam akronim ADDIE, yang merupakan komponen penting dalam proses mewujudkan reka bentuk 
pengajaran, iaitu analisis, reka Bentuk, pembangunan pelaksanaan, dan penilaian. Setiap fasa dalam model ADDIE berkaitan dan berinteraksi antara satu sama lain. Terdapat lima fasa yang terkandung dalam model ADDIE. Lima fasa yang terlibat adalah fasa analisa, fasa reka bentuk, fasa pembangunan, fasa pelaksanaan dan fasa terakhir ialah fasa penilaian.

Jadual 2. Perbandingan Metodologi

\begin{tabular}{|c|c|c|c|}
\hline Input & Model ADDIE & Model ASSURE & $\begin{array}{c}\text { Model Spire / } \\
\text { Waterfall }\end{array}$ \\
\hline 音 & $\begin{array}{l}\text { Model ini mengandngi } \\
\text { lima fasa utama yang } \\
\text { mampu dilaksanakan } \\
\text { secara berperingkat dan } \\
\text { lebih sistematik. }\end{array}$ & $\begin{array}{l}\text { Proses pengajaran } \\
\text { menjadi lebih } \\
\text { berkesan kerana } \\
\text { pengajaran yang } \\
\text { bersistematik. }\end{array}$ & $\begin{array}{l}\text { Kualiti dari sistem yang } \\
\text { dihasilkan akan baik. } \\
\text { Ini kerana } \\
\text { pelaksanaannya } \\
\text { dilakukan secara } \\
\text { bertahap. }\end{array}$ \\
\hline 离 & $\begin{array}{l}\text { Tidak } \\
\text { menggambarkan } \\
\text { hakikat dan suasana } \\
\text { yang sebenar tentang } \\
\text { proses pengajaran dan } \\
\text { pembelajaran. }\end{array}$ & $\begin{array}{l}\text { Kemudahan alatan } \\
\text { teknologi yang } \\
\text { kurang dan tidak } \\
\text { lengkap. }\end{array}$ & $\begin{array}{l}\text { Diperlukan pengurusan } \\
\text { yang baik, kerana } \\
\text { proses pengembangan } \\
\text { tidak dapat dilakukan } \\
\text { secara berulang } \\
\text { sebelum terjadinya } \\
\text { sesuatu produk. }\end{array}$ \\
\hline 氛 & \multicolumn{3}{|c|}{$\begin{array}{l}\text { Pembangunan koswer MySimba Apps terlebih dahulu akan melihat kepada } \\
\text { aspek input bahan pengajaran yang bersesuaian, berfokus kepada } \\
\text { interaktiviti dan reka bentuk dari koswer sedia ada di pasaran. Oleh itu, } \\
\text { kelebihan dan kelemahan sesuatu model itu perlu dikenalpasti terlebih } \\
\text { dahulu sebelum pelaksanaan produk koswer. }\end{array}$} \\
\hline
\end{tabular}

\subsubsection{Fasa Analisis}

Fasa analisis (analysis) melibatkan kajian terhadap masalah yang berpotensi untuk dipilih sebagai tajuk projek dan persekitarannya. Kajian dan pembacaan dilakukan terhadap tren atau teknologi semasa, buku, literasi, jurnal, internet dan bahan ilmiah lain Setelah diperhalusi dari segenap segi dan potensi, barulah skop dan keperluan projek ditetapkan. Dalam fasa ini juga, analisis kandungan perlu difokuskan dari segi kesesuaian kandungan dan sasaran pengguna. Hal ini adalah supaya koswer yang ingin dibangunkan mencukupi dan selaras dengan keperluan pengguna. Selain itu, analisis juga perlu dilakukan terhadap keperluan dari segi perisian dan perkakasan. Perisian yang digunakan adalah seperti Microsoft Words dan Microsoft Powerpoint dan perisian lain yang berkaitan. Dalam fasa analisa ini juga pemahaman masalah, proses serta kaedah penyelesaian masalah diperoleh dan didokumentasikan dalam bentuk kertas cadangan (proposal) yang dinamakan; "Koswer Pembelajaran Multimedia Interaktif Dalam Pengajaran Simpulan Bahasa Pelajar Darjah 6". Matlamat dan objektif yang ingin dicapai melalui pembangunan koswer ini perlulah jelas dan boleh dicapai dalam tempoh masa yang telah ditetapkan. Justeru, fasa analisis berfokus kepada analisis keperluan dari segi kandungan, perisian dan perkakasan yang digunakan.

\subsubsection{Fasa Reka Bentuk}

Fasa kedua ialah fasa reka bentuk (Design). Fasa reka bentuk adalah langkah seterusnya dalam model ADDIE. Fasa ini adalah mengenai penerapan arahan. Dalam fasa ini gambaran umum tentang pelaksanaan koswer akan digambarkan menggunakan kaedah visual seperti rajah, carta alir, diagram aliran data (DFD) dan lakaran antara muka koswer. Reka bentuk ini merangkumi aspek komunikasi koswer secara umum serta turutan proses secara spesifik dan memudahkan pihak-pihak yang berkaitan untuk memahami perjalanan koswer seterusnya menilai kesesuaian dan potensi untuk diteruskan pembangunannya. Secara kesimpulannya, fasa ini pembangun akan menumpukan kepada penilaian 
terhadap penggunaan konsep papan cerita (storyboard).

\subsubsection{Fasa Pembangunan}

Dalam fasa pembangunan (developement), prototaip dibangunkan berdasarkan maklumat yang diperolehi dari fasa- fasa terdahulu terutamanya fasa reka bentuk di mana aplikasi dibina menggunakan perisian multimedia seperti Microsoft Words, Microsoft Powerpoint dan perisian lain yang berkaitan. Aplikasi yang dibina ini akan diuji setelah siap dilaksanakan. Aspek kedua prototaip pula adalah membina dan menguji aplikasi berorientasikan koswer. Tegasnya, fasa pembangunan ini bergantung pada dua fasa pertama, iaitu analisis dan fasa reka bentuk. Ini bermakna jika kita melakukan fasa-fasa ini dengan betul, pembangunan akan lebih mudah. Pada fasa ketiga ini, pereka pengajaran mengintegrasikan teknologi dengan persekitaran dan proses pendidikan. Rancangan cadangan juga perlu sekiranya teknologi yang kita pilih tidak berfungsi.

\subsubsection{Fasa Pelaksanaan}

Fasa pelaksanaan (implementation) dijalankan selepas tamatnya fasa pembangunan. Di peringkat permulaan, prototaip akan diuji melalui penghasilan koswer. Pengujian ini adalah berdasarkan keceriaan antara muka, kesesuaian dan kepadatan input pengajaran, animasi yang menarik, bunyi dan bercirikan interaktif di mana pengguna dapat berinteraksi dengan perisian. Sekiranya pembangunan berjaya dalam peringkat ini, peringkat seterusnya adalah menyediakan dokumentasi, melakukan instalasi di lokasi pengguna yang terbabit, memberi penerangan, demonstrasi dan melakukan aktiviti kaji selidik untuk mendapatkan maklum balas pengguna.

\subsubsection{Fasa Penilaian}

Dalam fasa penilaian (evaluation) kemampuan dan kebekersanan prototaip akan dinilai berdasarkan kejayaan mencapai objektif yang dinyatakan diperingkat fasa analisa. Ia juga dinilai berdasarkan kepada maklum balas pengguna yang menggunakan prototaip ini dan juga daripada panel penilai itu sendiri. Kaedah yang bersesuaian seperti peredaran boring kaji selidik dan seterusnya menganalisa maklumatmaklumat yang diperolehi. Maklumat yang telah siap dianalisa akan dijadikan panduan bagi membantu aktiviti penambahbaikan (improvement), perkembangan dan penghasilan prototaip dan diperingkat seterusnya.

\section{Analisis Dapatan Kajian}

\subsection{Reka Bentuk Aplikasi}

Paparan menu utama memperlihatkan tajuk perisian koswer iaitu Mari Belajar Simpulan Bahasa. Gambar rajah menu utama terdiri daripada sub-sub tajuk iaitu kenal bentuk simpulan bahasa, tahu maksud setiap ayat simpulan bahasa, membunyikan ayat simpulan bahasa, kredit dan keluar (rujuk Rajah 1).

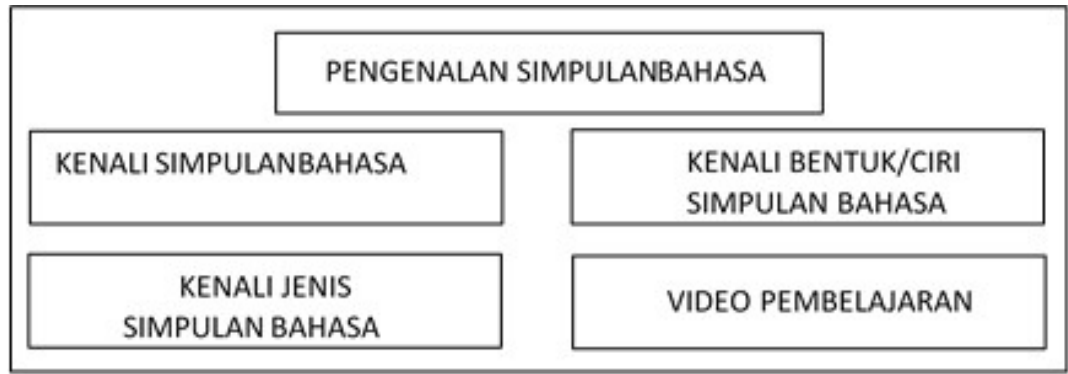

Rajah 1. Paparan Menu Utama

\subsection{Responden}

Responden yang digunakan dalam kajian ini adalah pelajar UPSI. Jadual 3 menunjukkan bahawa 40\% atau 12 orang daripada keseluruhan 30 jumlah responden adalah lelaki dan $60 \%$ atau 18 orang responden perempuan dipilih dalam analisis ini. Kesemua responden adalah pelajar UPSI dan telah mempelajari 
mata pelajaran bahasa Melayu darjah 6 bermula dari mereka di darjah satu peringkat persekolahan.

Jadual 3. Taburan Responden Mengikut Jantina

\begin{tabular}{|l|c|c|}
\hline Bangsa & Frekuensi & Peratus (\%) \\
\hline Lelaki & 12 & 40 \\
\hline Perempuan & 18 & 60 \\
\hline
\end{tabular}

Jadual 4 menunjukkan bahawa $80.0 \%$ atau 24 orang daripada keseluruhan 30 jumlah responden adalah berbangsa Melayu, 3.3\% atau seorang responden berbangsa Cina, $6.7 \%$ atau 2 orang responden berbangsa India dan $10 \%$ atau 3 orang responden adalah lain-lain bangsa dipilih dalam analisis ini. Kesemua responden mempunyai latar bangsa yang berbeza.

Jadual 4. Taburan Responden Mengikut Bangsa

\begin{tabular}{|l|l|l|}
\hline Bangsa & Frekuensi & Peratus (\%) \\
\hline Melayu & 24 & 80.0 \\
\hline Cina & 1 & 3.3 \\
\hline India & 2 & 6.7 \\
\hline Lain-lain & 3 & 10.0 \\
\hline
\end{tabular}

\subsection{Analisis Kandungan Koswer}

Merujuk kepada item "Adakah susunan teks dan bahan yang digunakan bersesuaian "menunjukkan seorang yang menjawab untuk bahagian sangat tidak setuju, tidak setuju dan tidak pasti. Seterusnya 6 orang atau $20.0 \%$ responden setuju dan 21 orang atau $70.0 \%$ responden sangat setuju bagi item ini. Skor min bagi item 1 melebihi 3.01 iaitu 4.50. Ini menunjukkan responden bersetuju bahawa mereka memahami kandungan koswer yang terdapat di dalam koswer MySimba yang dibangunkan.

Merujuk kepada item "Adakah penggunaan butang menu yang disediakan mudah" menunjukkan tiada yang menjawab untuk bahagian sangat tidak setuju, 2 orang atau $6.7 \%$ responden tidak setuju, seorang $3.3 \%$ orang yang tidak pasti. Seterusnya 4 atau $13.3 \%$ responden yang setuju dan 23 orang atau $76.7 \%$ responden sangat setuju bagi item ini. Skor min bagi item 2 melebihi 3.01 iaitu 4.60. Ini menunjukkan responden bersetuju bahawa mereka memahami kandungan koswer yang terdapat di dalam koswer MySimba yang dibangunkan.

Merujuk kepada item "Adakah penggunaan warna dan tema yang menarik dan bersesuaian" menunjukkan seorang yang menjawab untuk bahagian sangat tidak setuju, tidak setuju dan tidak pasti. Seterusnya 2 orang atau $6.7 \%$ responden setuju dan 25 orang atau $83.3 \%$ responden sangat setuju bagi item ini. Skor min bagi item 3 melebihi 3.01 iaitu 4.63. Ini menunjukkan responden bersetuju bahawa mereka memahami kandungan koswer yang terdapat di dalam koswer MySimba yang dibangunkan.

Merujuk kepada item "Adakah isi kandungan tersusun dan mudah difahami” menunjukkan 2 orang atau $6.7 \%$ yang menjawab untuk bahagian sangat tidak setuju dan tidak setuju. Seterusnya tiada yang menjawab untuk bahagian tidak pasti, sebanyak 7 orang atau $23.3 \%$ responden setuju dan 25 orang atau $63.3 \%$ responden sangat setuju bagi item ini. Skor min bagi item 4 melebihi 3.01 iaitu 4.30. Ini menunjukkan responden bersetuju bahawa mereka memahami kandungan koswer yang terdapat di dalam koswer MySimba yang dibangunkan.

Merujuk kepada item "Adakah pemilihan video menepati dengan isi kandungan" menunjukkan tiada yang menjawab untuk bahagian sangat tidak setuju, 3 orang atau $10.0 \%$ yang menjawab untuk bahagian tidak setuju dan setuju. Seterusnya seorang atau 3.3\% menjawab untuk bahagian tidak pasti dan 23 orang atau $76.7 \%$ responden sangat setuju bagi item ini. Skor min bagi item 5 melebihi 3.01 iaitu 4.53. Ini menunjukkan responden bersetuju bahawa mereka memahami kandungan koswer yang terdapat di dalam koswer MySimba yang dibangunkan.

Merujuk kepada item "Adakah pemilihan grafik sesuai dan menarik" menunjukkan tiada yang menjawab untuk bahagian sangat tidak setuju, 6 orang atau 20.0\% yang menjawab untuk bahagian tidak 
setuju dan seorang atau 3.3\% menjawab untuk bahagian tidak pasti. Seterusnya, 7 orang atau 23.3\% responden setuju dan 17 orang atau $56.7 \%$ menjawab sangat setuju bagi item ini. Skor min bagi item 6 melebihi 3.01 iaitu 4.10. Ini menunjukkan responden bersetuju bahawa mereka memahami kandungan koswer yang terdapat di dalam koswer MySimba yang dibangunkan.

Merujuk kepada item 7" Adakah pautan - pautan berfungsi sepenuhnya dengan tepat" menunjukkan 2 orang atau $6.7 \%$ yang menjawab untuk bahagian sangat tidak setuju, 5 orang atau $16.7 \%$ responden tidak setuju, tiada yang menjawab untuk bahagian tidak pasti. Seterusnya 7 orang atau $23.3 \%$ yang setuju dan 18 orang atau $60.0 \%$ responden yang menjawab sangat setuju bagi item ini. Skor min bagi item 7 melebihi 3.01 iaitu 4.00. Ini menunjukkan responden bersetuju bahawa mereka memahami kandungan koswer yang terdapat di dalam koswer MySimba yang dibangunkan.

Merujuk kepada item "Adakah saiz teks yang digunakan sesuai dan mudah dibaca" menunjukkan tiada yang menjawab untuk bahagian sangat tidak setuju. 1 orang atau $3.3 \%$ responden tidak setuju dan tidak pasti, Seterusnya 4 orang atau $10.0 \%$ yang setuju dan 24 orang atau $80.0 \%$ responden yang menjawab sangat setuju bagi item ini. Skor min bagi item 8 melebihi 3.01 iaitu 4.70. Ini menunjukkan responden bersetuju bahawa mereka memahami kandungan koswer yang terdapat di dalam koswer MySimba yang dibangunkan.

Merujuk kepada item "Adakah pengguna mudah menggunakan koswer MySimba untuk mencapai maklumat yang diperlukan" menunjukkan tiada yang menjawab untuk bahagian sangat tidak setuju. 1 orang atau $3.3 \%$ responden tidak setuju dan tidak pasti, Seterusnya 4 orang atau $10.0 \%$ yang setuju dan 24 orang atau $80.0 \%$ responden yang menjawab sangat setuju bagi item ini. Skor min bagi item 9 melebihi 3.01 iaitu 4.70. Ini menunjukkan responden bersetuju bahawa mereka memahami kandungan koswer yang terdapat di dalam koswer MySimba yang dibangunkan.

Merujuk kepada item "Saya sangat berpuas hati dengan koswer yang dibangunkan menunjukkan tiada yang menjawab untuk bahagian sangat tidak setuju. 1 orang atau 3.3\% responden tidak setuju dan tidak pasti, Seterusnya 4 orang atau $10.0 \%$ yang setuju dan 24 orang atau $80.0 \%$ responden yang menjawab sangat setuju bagi item ini. Skor min bagi item 10 melebihi 3.01 iaitu 4.70. Ini menunjukkan responden bersetuju bahawa mereka memahami kandungan koswer yang terdapat di dalam koswer MySimba yang dibangunkan.

\subsection{Analisis Kebolehgunaan Koswer}

Merujuk kepada item "Adakah nota dan video pembelajaran yang ada di dalam koswer MySimba mudah difahami" menunjukkan tiada yang menjawab untuk bahagian sangat tidak setuju, seorang atau 3.3\% responden tidak setuju, 3 orang $10.0 \%$ orang yang tidak pasti. Seterusnya 13 atau $43.3 \%$ responden yang setuju dan menajawab sangat setuju bagi item ini. Skor min bagi item 1 melebihi 3.01 iaitu 4.27. Ini menunjukkan responden bersetuju bahawa mereka memahami kebolehgunaan setiap fungsi koswer yang terdapat di dalam koswer MySimba yang dibangunkan.

Merujuk kepada item "Adakah bahan pembelajaran dalam koswer MySimba ini membantu dalam proses pembelajaran" menunjukkan tiada responden yang menjawab bahagian sangat tidak setuju. Seramai 3 orang atau $10.0 \%$ responden menjawab tidak setuju dan tidak pasti. Seterusnya 7 orang atau 23.3 setuju dan 17 orang atau 56.7\% responden sangat setuju bagi item ini. Skor min bagi item 2 melebihi 3.01 iaitu 4.27. Ini menunjukkan responden bersetuju bahawa mereka memahami kebolehgunaan setiap fungsi koswer yang terdapat di dalam koswer MySimba yang dibangunkan.

Merujuk kepada item "Adakah koswer MySimba ini menggunakan susun atur yang sistemati " menunjukkan kosong pada bahagian yang menjawab sangat tidak setuju, seramai 2 orang atau $6.7 \%$ responden tidak bersetuju, 6 orang atau $20.0 \%$ responden tidak pasti dan 8 orang atau $26.7 \%$ responden setuju. Seterusnya untuk sangat setuju iaitu seramai 14 orang atau $46.7 \%$ bagi item ini. Skor min bagi item 3 melebihi 3.01 iaitu 4.13. Ini menunjukkan responden bersetuju bahawa mereka memahami kebolehgunaan setiap fungsi koswer yang terdapat di dalam koswer MySimba yang dibangunkan.

Merujuk kepada item "Saya dapat mempelajari penggunaan kata Simpulan Bahasa di dalam koswer MySimba" menunjukkan tiada responden yang menjawab sangat tidak setuju dan tidak setuju, 2 orang atau $6.7 \%$ responden tidak pasti,5 orang atau $16.7 \%$ responden setuju dan 23 orng atau $76.7 \%$ responden sangat setuju dengan item ini. Skor min bagi item 4 melebihi 3.01 iaitu 4.70. Ini menunjukkan responden bersetuju bahawa mereka memahami kebolehgunaan setiap fungsi koswer yang terdapat di dalam koswer MySimba yang dibangunkan.

Merujuk kepada item "Panduan pengguna memudahkan saya untuk menggunakan koswer MySimba ini“" menunjukkan tiada responden yang menjawab sangat tidak setuju dan tidak setuju, 5 orang atau $16.7 \%$ responden tidak pasti, 3 orang atau $10.0 \%$ responden setuju dan 22 orang atau $73.3 \%$ responden 
sangat setuju bagi item ini. Skor min bagi item 5 melebihi 3.01 iaitu 4.57. Ini menunjukkan responden bersetuju bahawa mereka memahami kebolehgunaan setiap fungsi koswer yang terdapat di dalam koswer MySimba yang dibangunkan.

Merujuk kepada item "Saya dapat mempelajari selain nota pembelajaran Simpulan Bahasa di dalam koswer MySimba" menunjukkan tiada responden yang menjawab sangat tidak setuju, tidak setuju dan tidak pasti. 8 orang atau $26.7 \%$ responden setuju dam seterusnya 22 orang atau $73.3 \%$ responden sangat setuju bagi item ini. Skor min bagi item 6 melebihi 3.01 iaitu 4.73. Ini menunjukkan responden bersetuju bahawa mereka memahami kebolehgunaan setiap fungsi koswer yang terdapat di dalam koswer MySimba yang dibangunkan.

Merujuk kepada item "Penggunaan elemen multimedia membantu saya untuk menggunakan koswer koswer ini" enunjukkan tiada responden menjawab sangat tidak setuju dan tidak pasti. Seterusnya, seorang atau $3.3 \%$ responden menjawab tidak setuju. 5 orang atau $16.7 \%$ setuju dan 24 orang atau $80.0 \%$ menjawab sangat setuju bagi item ini. Skor min bagi item 7 tidak melebihi 3.01 iaitu 4.73. Ini menunjukkan responden bersetuju bahawa mereka memahami kebolehgunaan setiap fungsi koswer yang terdapat di dalam koswer MySimba yang dibangunkan.

Merujuk kepada item "Aras yang berbeza dalam kuiz yang disediakan dapat meningkatkan tahap kefahaman saya dalam Simpulan Bahasa" menunjukkan tiada responden yang menjawab sangat tidak setuju dan tidak setuju, 4 orang atau $13.3 \%$ responden tidak pasti, 6 orang atau $20.0 \%$ dan 20 orang atau $66.7 \%$ responden sangat setuju bagi item ini. Skor min bagi item 8 melebihi 3.01 iaitu 4.53. Ini menunjukkan responden bersetuju bahawa mereka memahami kebolehgunaan setiap fungsi koswer yang terdapat di dalam koswer MySimba yang dibangunkan.

Merujuk kepada item "Kuiz yang diberikan bersesuaian dengan aras yang dipilih" menunjukkan tiada responden menjawab sangat tidak setuju dan tidak pasti, 4 orang atau $13.3 \%$ responden tidak pasti, 6 orang atau $20.0 \%$ responden setuju dan 20 orang atau $66.7 \%$ responden sangat setuju bagi item ini. Skor min bagi item 9 melebihi 3.01 iaitu 4.40. Ini menunjukkan responden bersetuju bahawa mereka memahami kebolehgunaan setiap fungsi koswer yang terdapat di dalam koswer MySimba yang dibangunkan.

Merujuk kepada item "Adakah secara keseluruhan ksower MySimba ini mesra pengguna" menunjukkan tiada responden menjawab sangat tidak setuju dan tidak pasti, 2 orang atau $6.7 \%$ responden tidak setuju, seramai 13 orang bersamaan $43.3 \%$ setuju dan 15 orang atau $50.0 \%$ responden sangat setuju bagi item ini. Skor min bagi item 10 melebihi 3.01 iaitu 4.37. Ini menunjukkan responden bersetuju bahawa mereka memahami kebolehgunaan setiap fungsi koswer yang terdapat di dalam koswer MySimba yang dibangunkan.

\section{Kesimpulan}

Sebagaimana yang telah dijelaskan di awal kajian ini, kajian ini dilakukan bagi menganalisa keperluan dari segi kandungan, perisian dan perkakasan koswer multimedia interaktif yang dibangunkan. Projek koswer MySimba yang dibangunkan ini akan mendorong pelajar untuk memahami topik Simpulan Bahasa dengan cara lebih mudah dan mendalam. Oleh itu, kandungan koswer yang dibangunkan ini perlu dikaji terlebih dahulu dari segi perisian dan perkakasan. Hal ini kerana pembangun perlu menghasilkan bahan pembelajaran yang mudah digunakan kerana ia melibatkan pelajar sekolah rendah untuk memahami topik Simpulan Bahasa dengan jauh lebih mudah. Justeru itu, analisa dari segi kandungan koswer perlu dipastikan bersesuaian dengan tahap pengguna sebelum digunakan secara meluas.

Seterusnya, sesuatu pembangunan projek perlu melalui beberapa fasa sebelum siap untuk dipasarkan kepada umum untuk menggunakannya. Oleh itu, projek pembangunan koswer multimedia interaktif perlu melalui lima fasa utama untuk menjayakan pembangunan koswer ini secara rasmi supaya dapat digunakan oleh oleh orang ramai khususnya golongan pelajar sekolah rendah. Antara lima fasa utama tersebut ialah fasa analisis, fasa rekabentuk, fasa pembangunan, fasa pelaksanaan dan diakhinya fasa penilaian. Oleh itu, lima fasa utama ini diukur melalui rekabentuk antara muka projek yang menjadi paparan awal kepada pengguna.

Hasil kajian ini turut menjelaskan mengenai model Model Acceptance Technology (TAM) yang digunakan dalam koswer multimedia interaktif yang dibangunkan. Hal ini kerana koswer multimedia interaktif yang telah dibangunkan perlu dipastikan kebolehgunaan, kebolehfungsian dan mesra pengguna sebelum dipasarkan kepada umum khususnya kepada golongan pelajar sekolah rendah. Model TAM ini menjadi kayu pengukur kepada kejayaan koswer yang telah dibangunkan supaya setiap fungsi butang yang terdapat di dalam koswer MySimba dapat digunakan secara keseluruhan dengan baik. 
Beberapa implikasi kajian:

1. Koswer Pembelajaran Interaktif

Koswer pembelajaran yang dilengkapi dengan grafik dan animasi yang berinteraktiviti secara tidak langsung dapat menarik minat pelajar sekolah. Pelajar sekolah akan tertarik dengan grafik dan elemen-elemen lain yang terkandung dalam koswer pembelajaran ini. Elemen paling penting ialah warna dan bunyi. Pemilihan warna serta bunyi yang menarik dapat menarik minat pelajar sekolah melihat dan mendengar apa yang terkandung dalam ksower ini. Selain itu, isi kandungan yang ringkas dan padat juga menjadi faktor yang mendorong mereka menggunakan koswer ini.

2. Menjimatkan Masa

Dengan menggunakan koswer pembelajaran ini juga, secara tidak langsung dapat menjimatkan masa dan tenaga pengajar dan pelajar itu sendiri. Isi kandungan yang padat dan sempurna tidak memerlukan mereka keluar mencari rujukan lain yang lebih sempurna. Ini sekaligus dapat menjimatkan masa tenaga pengaajr dan membantu mereka dalam proses PdP.

3. Faedah Kepada Guru

Banyak faedah yang diperoleh oleh para guru kerana dengan penggunaan koswer, ia dapat membantu guru dalam menjalankan tugas. Melalui kajian yang dijalankan, penggunaan pembelajaran ksower dapat meringankan tugas baru. Walaubagaimanapun, penggunaan koswer bukanlah bertujuan mengambil alih seratus peratus tugas pendidik, tetapi membantu tugas guru semasa proses PdP. Dengan koswer pembelajaran, ia dapat membantu guru meningkatkan minat dan prestasi pelajar. Ini bermakna penggunaan koswer pembelajaran bukan sekadar memberi keseronokan semata-mata, tetapi amat berguna dalam peningkatan ingatan pelajar.

4. Faedah Kepada Ibu Bapa

Secara amnya, ibu bapa juga turut mendapat faedah dengan adanya koswer pembelajaran ini. Para ibu bapa tidak perlu membeli buku yang tebal dan mahal untuk dijadikan rujukan anakanak tetapi cukup dengan membayar harga sekeping CD pembelajaran sahaja. Harganya tidaklah semahal buku di mana mereka tidak perlu menghabiskan puluhan ringgit semata-mata untuk satu subjek sahaja.

Penghasilan koswer ini adalah sebagai satu penyediaan alternatif terhadap kaedah PdP. Seperti yang diketahui umum, tanpa koswer pembelajaran kaedah pembelajaran akan lebih berpusatkan kepada guru semata-mata. Guru menjadi sumber rujukan dan tempat pertanyaan pelajar untuk mendapatkan rujukan dan untuk bertanyakan masalah pembelajaran. Melalui corak pembelajaran melalui koswer ini, pelajar boleh menguasai sebahagian besar isi kandungan mata pelajaran di mana koswer dapat meringankan tugas guru dan meringankan tugas guru dan membolehkan mereka Dengan adanya koswer ini, ianya dapat menyumbang kepada usaha memperbaiki sistem pendidikan negara. Contohnya, dengan adanya koswer, guru dapat mempelbagaikan kaedah pengajaran. Pelajar pula mendapat bahan rujukan yang lengkap dan sempurna. Secara ringkasnya, bab ini membincangkan peripentingnya penggunaan koswer dalam PdP serta kelebihan-kelebihan yang diperolehi hasil daripada penggunaan koswer ini baik kepada guru, pelajar, ibu bapa juga kepada pihak-pihak lain. Selain itu, hampir keseluruhan objektif pembangunan koswer interaktif ini telah tercapai dan cadangan-cadangan penambahbaikan juga turut dipersembahkan bagi meningkatkan lagi mutu atau kualiti koswer ini di masa hadapan.

\section{Rujukan}

[1] UNESCO, "Bahagian Perancangan dan Penyelidikan Dasar Pendidikan Kementerian Pendidikan Malaysia," Jurnal Penyelidikan Pendidikan, pp. 13, 2018.

[2] Stephen, "Supporting Young Children's Learning with Technology at Home and in Preschool," Research Papers in Education, vol. 25, no. 1, pp. 93-113, 2017.

[3] Akmal, "Kemahiran dan Teknologi dalam Menghasilkan Sumber Manusia Yang Mampu Meningkatkan Mutu Keja dan Produktiviti," Trends in Undergraduate Research, vol. 1, no. 1, pp. 45-49, 2018.

[4] C. Brendon, M. Paustian, and T. Yates, "Self-Fulfilling Recessions at the Zero Lower Bound," Journal of Monetary Economics, vol. 115, pp. 213-232, 2020.

[5] M. A. Ishak, M. R. Kosnan, and N. F. Zakaria, "Build IoT through Virtual Reality", International Journal of Multimedia and Recent Innovation, vol. 2, no. 1, pp. 11-25, Mar. 2020. 
[6] N. A. N. Ibharim, S. Z. Ramli, S. A. Zahari, N. A. A. Edyanto, and M. A. Abdullah Zawawi, "Learning History Using Augmented Reality", International Journal of Multimedia and Recent Innovation, vol. 3, no. 1, pp. 1-10, Mar. 2021.

[7] N. H. Rahani, A. A. Bilong, M. R. Mat Suruji, and I. Y. Panessai, "Learning Logic Gates Using Augmented Reality", International Journal of Multimedia and Recent Innovation, vol. 2, no. 1, pp. 26-44, Mar. 2020.

[8] A. Z. Zakaria, H. Hassan, H. Halim, W. A. N. Wan Idris, M. A. Abdullah Zawawi, and N. F. Mansor, "Learning Mathematics: One Minute", International Journal of Multimedia and Recent Innovation, vol. 2, no. 2, pp. 76-86, Sep. 2020.

[9] S. N. S. Abu Samah, "The Efficacy of Augmented Reality on Student Achievement and Perception among Teluk Intan Community College Student in Learning 3D Animation", International Journal of Multimedia and Recent Innovation, vol. 2, no. 2, pp. 87-95, Sep. 2020.

[10] Z. Zainal Abidin and M. A. Abdullah Zawawi, "OOP-AR: Learn Object Oriented Programming Using Augmented Reality", International Journal of Multimedia and Recent Innovation, vol. 2, no. 1 , pp. 60-75, Mar. 2020.

[11] B. Hisham, N. A. F. Nadiah dan M. Yusri, "Revolusi Teknologi Maklumat," TINTA, vol. 24, no. 1, pp. 34-41, 2015.

[12] R. A. Rahman, M. Basri, K. Husain, C. W. S. B. C. W. Ahmad and M. S. N. M. Danuri, "Teknologi Maklumat dan Komunikasi (ICT) dalam Kehidupan Insan: Integrasi Konsep Dualiti (Kovensional dan Islam) dalam Silibus Kursus Pengantar IT," Jurnal Sultan Alauddin Sulaiman Shah, pp. 127, 2017.

[13] N. S. E. Saharudin, N. F. Mustapha and H. A. Halim, "Motivasi Pelajar Terhadap Penggunaan Teknologi Maklumat dan Komunikasi (ICT) dalam Pembelajaran Bahasa Perancis," Jurnal Kemanusiaan, pp. 13-17, 2017.

[14] Mohd. Yusof, "Kepentingan Penggunaan Media Sosial Teknologi Maklumat dalam Pendidikan IPTA," Journal of Social Sciences and Humanities, pp. 12, 2017.

[15] S. Z. Salsidu, M. N. A. Azman and M. S. Abdullah, "Tren Pembelajaran Menggunakan Multimedia Interaktif dalam Bidang Pendidikan Teknikal," Sains Humanika, pp. 135-141, 2017.

[16] R. E. Indrajit, "Information Technology and Individual Factors on Knowledge sharing Activites. Conference," in 2017 2nd International Conference on Knowledge Engineering and Applications (ICKEA), 2017.

[17] N. Hamzah, "Teknologi Maklumat dalam Pendidikan," Journal of Social Science and Humanities, pp. 11-12, 2018.

[18] S. M. Noor and M. Salih, "Koswer Visual Assisted Teaching Aid (vata) dalam Menangani Miskonsepsi dan Meningkatkan Kefahaman Murid Mengenai Konsep Fasa-Fasa Bulan," Bahagian Sitasi \& Infometriks, pp. 22-28, 2016.

[19] H. F. Hanafi, N. A. A. Zaki and M. H. A. Wahab, "Pembangunan dan Penilaian Koswer Multimedia "Computer Networks \& Communications"," in Conference Regional Conference on Knowledge and Integration in ICT, 2010.

[20] S. Suhaila and Sutaji, Kesan Penggunaan Koswer Multimedia Animasi Visual Terhadap Pencapaian Pelajar dalam Matapelajaran Matematik. Johor: Fakulti Pendidikan Teknikal dan Vokasional UTHM, 2015.

[21] N. Hamzah, A. Ariffin, S. N. Rubbani, and T. S. Subramanian, "Pembangunan Koswer Pembelajaran Berbantukan computer Bagi Topik Proses Penerbitan Animasi," Online Journal for TVET Practitioners, vol. 3, no. 2, 2018.

[22] M. Hashim, Kesan Multimedia Pemujukan Kesedaran Obesiti Ke Atas Pengetahuan, Kesedaran dan Motivasi Murid Yang Berbeza Jenis Motivasi. Johor: Fakulti Pendidikan Teknikal dan Vokasional UTHM, 2018. 